\title{
Completely calcified non-functioning kidney: a classical image of putty kidney
}

\author{
Vinod Priyadarshi, Hemant Kumar Goel, Malay Kumar Bera, Dilip Kumar Pal
}

Department of Urology, Institute of Post graduate Medical Education \& Research, Kolkata, West Bengal, India

\section{Correspondence to} Professor Dilip Kumar Pal, drdkpal@yahoo.co.in

Accepted 24 July 2014

\section{CrossMark}

To cite: Priyadarshi $\mathrm{V}$ Goel HK, Bera MK, et al. BMJ Case Rep Published online: [please include Day Month Year] doi:10.1136/ bcr-2013-203030

\section{DESCRIPTION}

A 56-year-old woman presented with symptoms of urgency, frequency and urge-incontinence for 3 years with intermittent episodes of fever. Her urine was acidic with few pus cells, but sterile on culture. Other laboratory tests were normal. Ultrasonography suggested hydronephrotic right kidney with internal echoes. X-ray kidney, ureter and bladder (KUB) show multiple lobulated calcifications in the right renal region conglomerated into the shape of the kidney (figure 1). Contrast-enhanced CT reaffirmed a densely calcified non-excretory right kidney with a small contracted bladder suggesting urinary tuberculosis with right putty kidney and a thimble bladder (figure 2). With antitubercular treatment for 8 weeks, right simple nephrectomy with ileocystoplasty was performed. The specimen was grossly calcified and histopathology was suggestive of caseous necrosis and calcifications (figure 3).

Diagnosis of genitourinary tuberculosis with urine culture or histopathology is often delayed. Therefore, radiological examination is used widely to determine the same. ${ }^{1}$ Primary renal infection remains confined in the glomeruli, but on

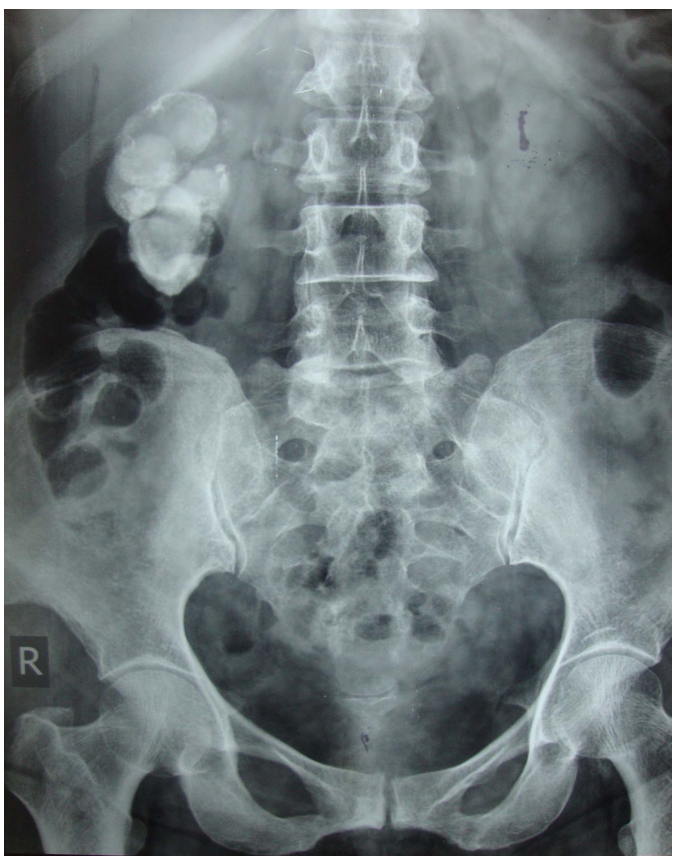

Figure 1 Diffuse alveolar calcification in right renal region in a shape of kidney.

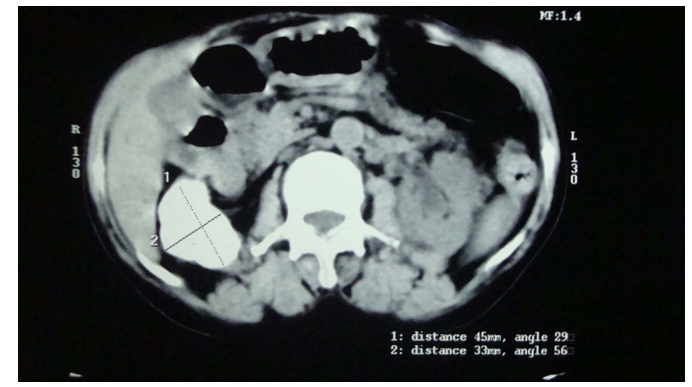

Figure 2 Contrast-enhanced CT showing completely calcified right kidney.

reactivation, it spreads into the medulla and interstitium. ${ }^{2}$ Disease progress with periodic ruptures, granuloma formation, caseous necrosis and cavitation within the renal parenchyma. Host's healing response induces fibrosis, calcium deposition, and stricture formation, which contribute to obstruction and progressive renal dysfunction. ${ }^{3}$ The end result of diffuse disease is destruction, loss of function and calcification of the entire kidney. ${ }^{2}$ Radiological findings in renal tuberculosis (TB) depend on the extent of the disease process and are best demonstrated on intravenous urogram and CT scan. Moth-eaten-calyx, amputated calyx, phantom calyx and autonephrectomy are seen with progress of disease. $^{2}$ Diffuse, uniform, extensive parenchymal calcifications in a non-functioning kidney forming a cast of the kidney is called as 'putty kidney' or 'autonephrectomy' and is a characteristic of endstage renal TB. ${ }^{1-3}$ The present X-ray KUB and CT is a classic example of such autonephrectomised putty kidney.

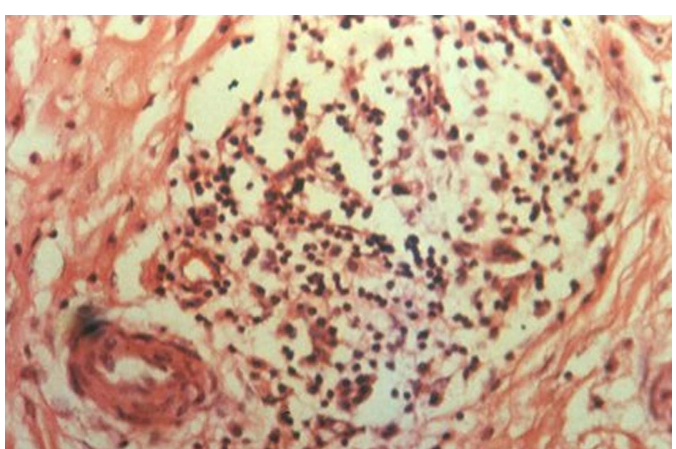

Figure 3 HPE of cold cup biopsy suggestive of grannulomatous cystitis (H\&E stain, $\times 10)$ 


\section{Learning points}

- Laboratory diagnosis in GUTB is often delayed and high index of suspicion required to procure them. Hence imaging has an important role in diagnosis.

- Radiological findings in renal tuberculosis (TB) depend on the extent of the disease process.

- Extensive parenchymal calcification in a non functioning kidney forming its cast is called a 'putty kidney' or 'autonephrectomy' which is a characteristic of end-stage renal TB.
Competing interests None.

Patient consent Obtained.

Provenance and peer review Not commissioned; externally peer reviewed.

\section{REFERENCES}

1 Jung YY, Kim JK, Cho KS. Genitourinary tuberculosis:comprehensive cross-sectional imaging. AJR Am J Roentgenol 2005;184:143-50.

2 Muttarak M, ChiangMai WN, Lojanapiw B. Tuberculosis of the genitourinary tract: imaging features with pathological correlation. Singapore Med J 2005;46:568.

3 Gibson MS, Puckett ML, Shelly ME. Renal tuberculosis. Radiographics 2004;24:251-6.

Copyright 2014 BMJ Publishing Group. All rights reserved. For permission to reuse any of this content visit http://group.bmj.com/group/rights-licensing/permissions.

BMJ Case Report Fellows may re-use this article for personal use and teaching without any further permission.

Become a Fellow of BMJ Case Reports today and you can:

- Submit as many cases as you like

- Enjoy fast sympathetic peer review and rapid publication of accepted articles

- Access all the published articles

- Re-use any of the published material for personal use and teaching without further permission

For information on Institutional Fellowships contact consortiasales@bmjgroup.com

Visit casereports.bmj.com for more articles like this and to become a Fellow 